\title{
PERAN KEPALA SEKOLAH DALAM MENINGKATKAN PROFESIONALISME GURU SMK (SEKOLAH MENENGAH KEJURUAN) DI KECAMATAN CURAHDAMI, BONDOWOSO
}

\author{
Nurma Yunita ${ }^{1}$, Supardi $^{2}$, Muhaimin Dimyati ${ }^{3}$ \\ STIE Mandala Jember 1,2,3 \\ Email : nurmay501@gmail.com ${ }^{1}$
}

\begin{abstract}
This research aim to examine principal's role as an educator, supervisor and motivator. Based on problem identification, the researcher will research about principal's role in improving teacher's professionalism in SMK Curahdami. Empower teacher's competencies, conduct training, special coaching program such as sertifikasi. In this case, sertifikasi can be used as teacher's skill measurement to be a professional teacher. The existence of this program will spur the spirit of teachers to improve themselves, improve the quality of knowledge, and professionalism in education.

Improving teacher's knowledge by delegating teacher in education activities such as workshop, improving teacher's creativity by motivate and support them in increasing their teaching ability.
\end{abstract}

Keywords: educator, supervisor, motivator

\section{Pendahuluan}

Pendidikan merupakan sesuatu yang sangat esensial bagi pembentukan karakter sebuah peradaban dan kemajuan yang mengiringinya. Tanpa pendidikan, sebuah bangsa atau masyararakat tidak akan pernah mendapatkan kemajuannya sehingga menjadi bangsa atau masyarakat yang kurang atau bahkan tidak beradab.

Pendidikan adalah wahana untuk mencetak generasi muda yang sangat penting bagi masa depan negeri ini. Tanpa adanya pendidikan yang baik dan berkualitas, tentu saja negeri ini akan terancam karena anak mudanya di didik secara serampangan dan tidak sesuai dengan nafas kemajuan zaman yang semakin cepat ini. Dan untuk mendapatkan pendidikan yang berkualitas tentu saja segala pihak yang berkompeten didalamnya harus bekerja keras untuk memberikan yang terbaik dalam memajukan pendidikan.

Perkembangan global dan era reformasi memacu bangsa Indonesia untuk meningkatkan kualitas sumber daya manusia. Karena dengan sumber daya manusia yang berkualitas merupakan modal utama dalam pembangunan di segala bidang sehingga diharapkan bangsa Indonesia dengan sumber daya manusianya sdapat bersaing dengan bangsa lain yang lebih maju. 
Pengembangan dan Peningkatan kualitas sumber daya manusia, merupakan peranan yang sangat penting pada dunia pendidikan, dan sangat diperlukan bagi pembangunan di segala bidang. Terutama mempersiapkan peserta didik menjadi aktor IPTEK yang mampu menampilkan kemampuan dirinya, sebagai sosok manusia Indonesia yang tangguh, kreatif, mandiri, dan prefesional di bidangnya.

Tujuan pendidikan nasional, dalam Garis Besar Haluan Negara (GBHN) adalah untuk meningkatkan kualitas manusia Indonesia. Yaitu manusia yang beriman dan bertaqwa terhadap Tuhan Yang Maha Esa budi pekerti luhur, berkepribadian, mandiri, maju, tangguh, cerdas, kreatif, terampil, berdisiplin, beretos kerja, profesional, bertanggung jawab, produktif, sehat jasmani dan rohani UUD RI No. 20 tahun 2003.

Tenaga pendidik merupakan salah satu tenaga kependidikan yang mempunyai peran sebagai salah satu faktor penentu keberhasilan tujuan pendidikan, karena guru yang langsung bersinggungan dengan peserta didik, untuk memberikan bimbingan yang akan menghasilkan tamatan yang diharapkan. Guru merupakan sumber daya manusia yang menjadi perencana, pelaku dan penentu tercapainya tujuan organisasi (Soejipto:2009:42).

Guru merupakan tulang punggung dalam kegiatan pendidikan terutama yang berkaitan dengan kegiatan proses belajar mengajar. Tanpa adanya peran guru maka proses belajar mengajar akan terganggu bahkan gagal. Oleh karena itu dalam manajemen pendidikan peranan guru dalam upaya keberhasilan pendidikan selalu ditingkatkan, kinerja atau prestasi kerja guru harus selalu ditingkatkan mengingat tantangan dunia pendidikan untuk menghasilkan kualitas sumber daya manusia mampu bersaing di Era Global.

Simamora menyatakan bahwa dalam Moh Uzer Usman bahwa kinerja merupakan suatu persyaratan-persyaratan tertentu yang ahrirnya secara langsung dapat tercermin dari output yang dihasilkan baik yang berupa jumlah maupun kualitasnya. Output yang dihasilkan menurut simamora dapat berupa fisik maupun nonfisik yang menyebutkan berupa karya, yaitu suatu hasil atau pekerjaan baik berupa fisik atau material maupun nonfisik maupun nonmaterial.

Seorang guru dalam mengerjakan tugasnya dengan baik, seringkali ditentukan oleh penilaian terhadap kinerjanya. Penilaian tidak hanya dilakukan untuk membantu mengawasi sumber daya organisasi namun juga untuk mengukur tingkat efisien penggunaan sumber daya yang ada dan mengidentifikasi hal - hal yang perlu diperbaiki. Penilaian terhadap kinerja merupakan faktor penting untuk meningkatkan kinerja dan kepuasan kerja guru, bagian-bagian yang menunjukkan kemampuan guru yang kurang dapat diidentifikasi, diketahui sehingga dapat ditentukan strategi meningkatkan kinerjanya.

Menurut Soebagio ( dalam Soetjupto, 2016: 14) kepemimpinan pendidikan memerlukan perhatian utama. Karena melalui kepemimpinan yang baik diharapkan akan lahir tenaga-tenaga berkualitas dalam berbagai bidang sebagai pemikir, pekerja yang pada ahirnya dapat meningkatkan sumber daya manusia yang berkualitas. Hal yang terpenting bahwa melalui pendidikan kita menyiapkan tenaga-tenaga yang terampil, berkualitas, dan tenaga yang siap pakai memenuhi kebutuhan masyarakat bisnis dan industri di dunia global. 
Menurut Raflis Kosasi dalam Soetjipto, 2009: 44 pada dasarnya kepala sekolah melakukan tiga fungsi sebagai berikut yaitu : membantu para guru memahami, memilih, dan merumuskan tujuan pendidikan yang akan dicapai, menggerakkan para guru, para karyawan, para siswa, dan anggota masyarakat untuk mensukseskan program-program pendidikan disekolah, menciptakan sekolah sebagai lingkungan kerja yang harmonis, sehat, dinamis, nyaman sehingga segenap anggota dapat bekerja dengan penuh produktivitas dan memperoleh kepuasan kerja yang tinggi.

Guru merupakan seorang pendidik, maka sebagai kepala sekolah harus mampu membina, memajukan, dan meningkatkan nilai mental, moral, fisik dan artistik kepada para tenaga pendidik serta tenaga kependidikan. Untuk dapat terwujudnya sebagai tenaga pendidik profesional peran kepala sekolah harus dapat menunjukkan sikap pesuasif dan keteladanan. Sikap persuasif dan keteladanan yang dapat mewarnai kepemimpinan termasuk didalamnya pembinaan yang dilakukan oleh kepala sekolah terhadap bawahannya. Kepala sekolah sebagai edukator, supervisor, motivator yang harus melaksanakan pembinaan kepada para karyawan, dan para guru di sekolah yang dipimpinnya karena faktor manusia merupakan faktor sentral yang menentukan seluruh gerak aktivitas guru organisasi, walaupun secanggih apapun teknologi yang digunakan tetap faktor manusia yang menentukannya (Suharsimi, 2010: 238-240).

Profesionalisme guru tidak akan ada atau berjalan mulus tanpa adanya usaha-usaha yang dilakukan oleh kepala sekolah, sebab salah satu diantara cara guru agar bisa menjadi profesional adalah dengan adanya upaya-upaya yang dilakukan oleh kepala sekolah dalam rangka meningkatkan kualitas guru. Berdasarkan latar belakang masalah diatas, peneliti tertarik melakukan penelitian dengan judul " Peran Kepala Sekolah dalam Meningkatkan Profesionalisme Guru SMK (Sekolah Menengah Kejuruan) di Kecamatan Curahdami Bondowoso.“

Penelitian ini bertujuan menguji Peran Kepala Sekolah dalam Meningkatkan Profesionalisme Guru SMK (Sekolah Menengah Kejuruan) di Kecamatan Curahdami Bondowoso. Penelitian ini mengacu pada penelitian penelitian sebelumnya, dengan beberapa persamaan maupun perbedaan. Kerangka pemikiran yang melandasi penelitian ini adalah rendahnya kualitas sumber daya manusia khususnya tenaga pendidik/guru merupakan salah satu masalah utama dalam dunia pendidikan.

Tenaga pendidik/guru merupakan salah satu komponen yang sangat penting dalam menentukan keberhasilan dalam mencapai sebuah tujuan pendidikan, oleh sebab itu guru harus berkualitas dan sesuai dengan standar profesional guru yang ada. Guru dituntut untuk meningkatkan kualitas dan kompetensinya sehingga guru harus dapat menguasai kompetensi guru yang telah ada. Oleh sebab itu, perlu adanya pembinaan yang dilakukan agar guru lebih baik dalam melaksanakan profesinya dalam mengajar di sekolah.

Tujuan pembinaan profesionalitas guru adalah untuk meningkatkan kualitas sumber daya tenaga kependidikan yang tersedia sehingga dapat meningkatkan kualitas proses pendidikan itu sendiri, dan pada gilirannya kualitas prestasi belajar dan output semakin bermutu. Bentuk-bentuk pembinaan guru yang dilakukan oleh kepala sekolah dalam meningkatkan profesionalitas guru diambil 
dari beberapa pendapat yaitu Ibrahim Bafadal dan Suryosubroto disebutkan bahwa pembinaan guru terdiri dari pembinaan supervisi, penataran, diskusi kelompok/kelompok kerja guru, seminar, ceramah ilmiah, karyawisata, diklat, bulletin organisasi.

Diharapkan dengan adanya pembinaan dari kepala sekolah tersebut, profesionalitas guru menjadi meningkat dan menjadi lebih baik lagi sehingga kegiatan belajar mengajar pun menjadi lebih efektif dan efisien. Berdasarkan hal tersebut diatas, maka dibuat skema kerangka pemikiran seperti di bawah ini.

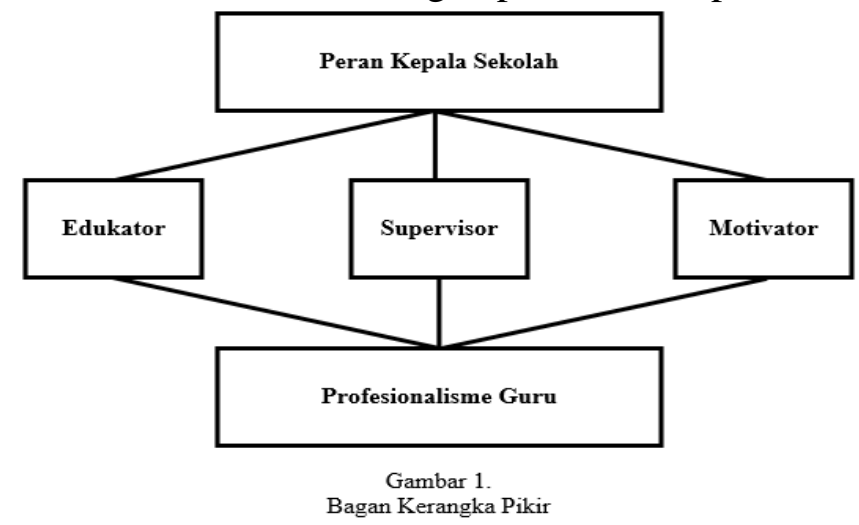

Penelitian saat ini adalah peneliti kualitatif. Penelitian jenis kualitatif disebut juga penelitian naturalistik, metode fenomenologis, metode impresionistik, dan metode post positivistic. Adapun karakteristik penelitian jenis ini adalah sebagai berikut (Sujana dan Ibrahim, 2001: 6-7; Suharsimi Arikunto, 2002: 11-12; Moleong, 2005: 8-11; Johnson, 2005, dan Kasiram, 2008: 154-155).

a. Menggunakan pola berpikir induktif (empiris - rasional atau bottom-up). Metode kualitatif sering digunakan untuk menghasilkan grounded theory, yaitu teori yang timbul dari data bukan dari hipotesis seperti dalam metode kuantitatif. Atas dasar itu penelitian bersifat generating theory, sehingga teori yang dihasilkan berupa teori substansif.

b. Perspektif emic/partisipan sangat diutamakan dan dihargai tinggi. Minat peneliti banyak tercurah pada bagaimana persepsi dan makna menurut sudut pandang partisipan yang diteliti, sehingga bias menemukan apa yang disebut sebagai fakta fenomenologis.

c. Penelitian jenis kualitatif tidak menggunakan rancangan penelitian yang baku. Rancangan penelitian berkembang selama proses penelitian.

d. Tujuan penelitian kualitatif adalah untuk memahami, mencari makna di balik data, untuk menemukan kebenaran, baik kebenaran empiris sensual, empiris logis, dan empiris logis.

e. Subjek yang diteliti, data yang dikumpulkan, sumber data yang dibutuhkan, dan alat pengumpul data bisa berubah-ubah sesuai dengan kebutuhan.

f. Pengumpulan data dilakukan atas dasar prinsip fenomenologis, yaitu dengan memahami secara mendalam gejala atau fenomena yang dihadapi.

g. Peneliti berfungsi pula sebagai alat pengumpul data sehingga keberadaanya tidak terpisahkan dengan apa yang diteliti. 
h. Analisis data dapat dilakukan selama penelitian sedang dan telah berlangsung.

i. Hasil penelitian berupa deskripsi dan interpretasi dalam konteks waktu serta situasi tertentu.

j. Penelitian jenis kualitatif disebut juga penelitian alamiah atau inquiri naturalistik.

\section{Metode Penelitian}

Menurut Arikunto (2006: 130) "Populasi adalah keseluruhan objek penelitian". Populasi dalam suatu penelitian merupakan sekumpulan objek yang dapat dijadikan sumber penelitian yang berbentuk benda-benda, manusia ataupun peristiwa yang terjadi sebagai objek atau sasaran penelitian. Hal ini sesuai dengan pendapat Silalahi, (2006:147) bahwa: "populasi merupakan jumlah total dari keseluruhan elemen yang dianalisis atau dipelajari. Populasi dapat berupa organisme, orang, benda, objek, peristiwa, atau laporan”. Populasi dalam penelitian ini seluruh guru dan kepala sekolah dari kedua SMK yaitu 30 orang guru dan 2 orang kepala sekolah.

Pengertian sampel menurut Sugiyono (2012:73) adalah bagian dari jumlah dan karakteristik yang dimiliki oleh populasi tersebut sampel yang diambil dari populasi tersebut harus betul-betul representative (mewakili). Ukuran sampel merupakan banyaknya sampel yang akan diambil dari suatu populasi. Menurut Arikunto (2012:104) jika jumlah populasinya kurang dari 100 orang, maka jumlah sampelnya diambil secara keseluruhan, tetapi jika populasinya lebih besar dari 100 orang, maka bisa diambil $10-15 \%$ atau $20-25 \%$ dari jumlah populasinya.

Berdasarkan penelitian ini karena jumlah populasinya tidak lebih besar dari 100 orang responden, maka penulis mengambil 100\% jumlah seluruh populasi yang ada pada kedua sekolah yaitu seluruh guru dan kepala sekolah dari kedua SMK sebanyak 30 orang guru dan 2 orang kepala sekolah atau sebanyak 94 orang responden. Dengan demikian penggunaan seluruh populasi tanpa harus menarik sampel penelitian sebagai unit observasi disebut sebagai teknik sensus.

\section{Jenis Penelitian}

Penelitian ini adalah penelitian lapangan (Field Research) dengan jenis deskriptip kualitatif. Menurut Lexy J. Moleong ( 2007: 6), Penelitian deskriptip adalah penelitian yang memberikan gambaran tentang situasi dan kejadian secara faktual dan sistematis mengenai faktor-faktor, sifat-sifat serta hubungan antara fenomena yang dimiliki untuk melakukan akumulasi dasar-dasarnya saja.

Menurut Sugiono (2008: 15), penelitian kualitatif adalah metode penelitian yang berlandaskan pada filsafat postpositivisme, digunakan untuk meneliti pada kondisi objek yang alamiah (sebagai lawannya adalah eksperimen). Peneliti adalah sebagai instrumen kunci, pengambilan sampel dilakukan secara purposive dan snowball, teknik pengumpulan dengan trianggulasi (gabungan), analisis dan bersifat induktif/kualitatif dan hasil penelitian lebih menekankan makna dari pada generalisasi. 
Penelitian ini meggunkan jenis penelitian deskriptif. Penelitian deskriptif (descriptive reasearch), yang biasa disebut juga penelitian taksonomik (taksonomic research), seperti telah disebutkan sebelumnya, dimaksudkan untuk eksplorasi dan klarifikasi mengenai suatu fenomena atua kenyataan sosial, dengan jalan mendeskripsikan sejumlah variabel yang berkenaan dengan masalah dan uinit yang diteliti. Jenis penelitian ini tidak sampai mempersoalkan jaringan hubungan antar variabel yang ada tidak maksudkan untuk menarik generasi yang menjelaskan variabel-varibel anteseden yang menyebabkan sesuatu gejala atau kenyataan sosial. Oleh karena itu, pada suatu penelitian deskriptif, tidak menggunakan dan tidak melakukan pengujian hipotesis (seperti yang dilakukan dalam penelitian eksplanasi) ; berarti tidak dimaksudkan unutk membangun dan mengembangkan perbendaharaan teori. Dalam pengelolahan dan analisis data, lazimnya menggunakan pengolahan statistik yang bersifat deskriptif (statistik deskriptif).

Penulis berupaya menggambarkan apa adanya atau mendeskripsikan secara faktual dan sistematis mengenai upaya kepala sekolah dalam meningkatkan profesionalisme guru SMK (Sekolah Menengah Kejuruan) di Kecamatan Curahdami Bondowoso. Disamping itu penulis juga akan mengemukakan faktor penghambat yang dihadapi dalam penelitian tersebut.

\section{Identifikasi Variabel}

Variabel penelitian adalah segala sesuatu yang berbentuk apa saja yang ditetapkan oleh peneliti untuk dipelajari sehingga diperoleh informasi tentang hal tersebut, kemudian ditarik kesimpulan (Sugiyono, 2013: 38). Variabel yang digunakan dalam penelitian ini adalah (1) peran kepala sekolah sebagai educator, (2) peran kepala sekolah sebagai supervisor (3) peran kepala sekolah sebagai motivator.

\section{Definisi Operasional Variabel Penelitian}

Definisi operasional pada penelitian adalah unsur penelitian yang terkait dengan variabel yang terdapat dalam judul penelitian atau yang tercakup dalam paradigma penelitian sesuai dengan hasil perumusan masalah. Teori ini dipergunakan sebagai landasan atau alasan mengapa suatu yang bersangkutan memang bisa memengaruhi variabel tak bebas (Supranto, 2003: 322).

- Peran kepala sekolah sebagai edukator harus memiliki strategi yang tepat untuk meningkatkan profesionalisme tenaga pendidik di SMK, menciptakan iklim pendidik yang kondusif, memberikan nasehat kepada warga SMK, memberikan dorongan kepada seluruh tenaga pendidik serta melaksanakan model pembelajaran yang menarik.

- Peran kepala sekolah sebagai supervisor harus dengan penuh tanggung jawab dan dengan sebagai supevisor harus dengan penuh tanggung dan dengan sebaik baiknya, agar tugas tersebut dapat berjalan dengan lancar.

- Peran kepala sekolah sebagai motivator berawal dari kata motif dapat dikatakan sebagai daya penggerak dari dalam dan di dalam subjek untuk melakukan aktivitas-aktivitas tertentu demi mencapai suatu tujuan. Berawal 
dari kata "motif" itu, maka motivasi dapat diartikan sebagai daya penggerak yang telah menjadi aktif.

\section{Metode Pengumpulan Data}

Prosedur pengumpulan data yang digunakan dalam penelitian ini adalah observasi, wawancara, dan dokumentasi

1. Teknik Observasi

Observasi merupakan segala hal yang berkaitan dengan proses penyelidikan untuk mengidentifikasi dan memahami variabel psikologis untuk penegakan diagnosis psikologis, yang didalamnya terdapat proses pengukuran dan penggunaan berbagai teknik untuk mampu memahami dan mendiagnosis variabel psikologis.

Teknik observasi digunakan untuk mengetahui secara langsung bagaimana Upaya Kepala Sekolah dalam Meningkatkan Profesionalisme Guru pada Prestasi Membaca Cepat Siswa Menengah Kejuruan Taruna Husada peneliti akan mempersiapkan lembar observasi, instrumen yang digunakan dalam observasi yaitu: kamera, alat tulis.

2. Teknik Wawancara

Teknik wawancara yang peneliti gunakan disini adalah wawancara terstruktur dan tidak terstruktur. Data yang diambil dari wawancara ini adalah data mengenai Upaya Kepala Sekolah dalam Meningkatkan Profesionalisme Guru pada Prestasi Membaca Cepat Siswa Menengah Kejuruan Taruna Husada.

Wawancara ini dilakukan dengan mengajukan sejumlah pertanyaanpertanyaan terlebih dahulu disusun sedemikian rupa. Dalam wawancara ini yang menjadi sasaran wawancara adalah Kepala Sekolah, Guru, Siswa. Instrumen yang digunakan dalam wawancara yaitu lembar pedoman wawancara (terlampir), alat tulis, HP.

3. Teknik Dokumentasi

Dokumentasi adalah salah satu eknik pengumpulan data yang menggunakan dokumen sebagai sumber peneltian. Guba dan Lincoln,2011:197 mendefinisikan dokumen sebagai berikut: dokumen adalah setiap bahan tertulis ataupun film, yang dipesiapkan karena adanya permintaan sorang penyidik Studi dokumentasi yaitu mengadakan pengujian terhadap dokumen yang dianggap mendukung hasil penelitian.

\section{Metode Analisis Data}

Adapun tahapan-tahapan analisis data menggunakan model Miles dan Huberman pada penelitian ini adalah sebagai berikut:

1. Reduksi data

2. Penyajian data

3. Menarik kesimpulan.

\section{Tekhnik Keabsahan Data}

Untuk memperkuat keabsahan data hasil temuan dan menjaga validitasi penelitian, maka peneliti mengacu pada empat standar validasi yang disarankan 
oleh Tohirin,2011:71-72 dan Rosady,2008:219-220 yaitu:

1. Kredibilitas (credibilty)

2. Keteralihan (trasferibility)

3. Ketergantungan ( dependanilly)

4. Ketegasan (comfirmabillty)

\section{Hasil Dan Pembahasan}

Berdasarkan hasil penelitian Peran Kepala Sekolah dalam Meningkatkan Profesionalisme Guru SMK di kecamatan curahdami kabupaten bondowoso sudah berjalan dengan baik, jika dilihat dari kerjasama tim yang bertanggung jawab yang dimiliki oleh kepala Sekolah, operator sekolah, guru dan orang-orang yang terlibat dalam meningkatkan kualitas pendidikan telah dilakukan secara baik, jelas dan terarah walaupun masih ada yang menjadi kendala-kendala dalam pelaksanaannya.

\begin{tabular}{|l|l|l|l|l|l|}
\hline No & Nama lembaga & $\begin{array}{l}\text { Jumlah } \\
\text { Guru }\end{array}$ & $\begin{array}{l}\text { Lulus } \\
\text { sertifikasi }\end{array}$ & $\begin{array}{l}\text { Tidak } \\
\text { lulus } \\
\text { UKG }\end{array}$ & $\begin{array}{l}\text { Tidak } \\
\text { lulus } \\
\text { Seleksi } \\
\text { Akademik }\end{array}$ \\
\hline 1 & SMK TARUNA HUSADA & 16 & 0 & 5 & 11 \\
\hline 2 & SMK RAUDLATUL HASAN & 14 & 2 & 8 & 4 \\
\hline & JUMLAH & 30 & 2 & 13 & 15 \\
\hline
\end{tabular}

Dari tabel di atas Jumlah guru di SMK Taruna Husada 16 dan SMK Raudlatul Hasan 14 total semua 30 guru. Guru yang sertifikasi 2 orang dari SMK Raudlatul Hasan, Guru yang tidak lulus UKG 13 orang dan Guru yang tidak lulus seleksi akademik 15 orang.

Guru professional mempunyai peranan penting dalam kegiatan belajar mengajar, karena hitam putihnya proses belajar mengajar di dalam kelas banyak dipengaruhi oleh mutu guru itu sendiri. Berkaitan dengan masalah pendidikan, maka kinerja guru merupakan salah satu faktor yang akan sangat menentukan terhadap kualitas proses dan hasil pendidikan. Guru merupakan profesi profesional di mana ia dituntut untuk berupaya semaksimal mungkin menjalankan profesinya sebaik mungkin. Sebagai seorang profesional maka tugas guru sebagai pendidik, pengajar dan pelatih hendaknya dapat berimbas kepada siswanya.

Dalam hal ini guru hendaknya dapat meningkatkan terus kinerjanya yang merupakan modal bagi keberhasilan pendidikan. Seorang guru yang professional harus memiliki sertifikat pendidik (sertifikasi guru) setelah lulus uji kompetensi yang diselenggarakan oleh lembaga sertifikasi.

Para guru SMK swasta yang ada di kecamatan curahdami yang telah mengikuti program sertifikasi guru, menunjukkan dari hasil penelitian bahwa dengan adanya pelatihan - pelatihan yang diikuti para guru yang telah tersertifikasi membawa banyak pengaruh terhadap kinerja guru dalam melaksanakan tugas sebagai pendidik.

Dari analisis di atas memperlihatkan bahwa pengaruh sertifikasi terhadap kinerja guru yang telah melaksanakan sertifikasi yaitu mereka selalu berupaya meningkatkan mutu professional mereka. Untuk mencapai kinerja guru yang 
tinggi dan maksimal setiap proses pembelajaran yang dilaksanakan, diperlukan adanya motivasi dari guru tersebut untuk meningkatkan kinerjanya secara utuh. Karena seorang guru akan berhasil jika guru tersebut mempunyai motivasi dalam kerja. Tinggi rendahnya motivasi seorang guru akan mempengaruhi keberhasilan dalam proses pendidikan dan akan berpengaruh pada kinerja guru tersebut. Dengan kata lain, apabila motivasi kerja guru tersebut rendah atau tidak terpenuhi kebutuhannya maka pengaruh terhadap kinerja yang dihasilkannya pun rendah atau tidak maksimal.

Tunjangan profesi itu diperlukan sebagai syarat mutlak sebuah profesi agar penyandang profesi dapat hidup layak dan memadai. Sehingga dapat meningkatkan kesejahteraan hidup guru maupun dalam melaksanakan tugasnya sebagai pendidik.

Adapun penjabaran dalam pembahasan ini yang berpedoman pada pertanyaan penelitian tentang:

1. Peran Kepala Sekolah sebagai Edukator, Supervisor dan Motivator Meningkatkan Profesionalisme Guru

Sebagai lembaga pendidikan yang bernaung pada Dinas pendidikan yang berada pada pemerintahan propinsi jawa timur, mengembang visi misi pendidikan, dimana dinamika pelaksanaan tugas dan tanggung jawabnya sebagai tenaga edukatif dituntut pelaksanaan tugas sebagai guru sedapat mungkin bertindak sebagai agen pembelajaran yang profesional. Dalam usaha memahami tugas dan tangung jawab tenaga pendidik dalam hal ini seorang guru, dalam acuan dan tujuan yang ingin dicapai dalam pembelajarannya adalah mengacu pada Undangundang Nomor : 20 Tahun 2003 dan undang - undang RI Nomor 14 tahun 2005 tentang guru dan dosen serta peaturan pemerintah RI Nomor 19 Tahun 2005 tentang Standar Nasional Pendidikan Menyatakan Guru adalah pendidik profesional.

Kepala sekolah selaku penangung jawab pengelolaan administrasi dan teknis pembelajaran diharapkan mampu bertindak selaku manajer dalam upaya menumbuh kembangkan kompetensi guru lewat pemberdayaan kompetensi guru melalui bentuk penghargaan seperti pemberian kesempatan sertifikasi guru, pendidikan dan latihan profesi, penyediaan sarana pendukung pembelajaran, pemerataan jam pelajaran, pemberian insentif berdasarkan tugas dan tanggung jawabnya serta pemenuhan jaminan kenyamanan dan keamanan dalam menjalankan jawaban serta pembelajarannya.

Upaya pembinaan kepala sekolah harus bisa memimpin bawahannya dengan melakukan berbagai kegiatan, baik interaksi antar pemimpin dan bawahannya juga teknik komunikasi yang tepat dan kepribadian yang positif, sehingga apa yang diinginkan dapat diikuti dengan baik dan terah. Dengan demikian tugas yang begitu banyak yang harus dilakukan oleh kepala sekolah dapat didelegasikan kepada guru tentunya dengan tepat, artinya guru dapat melaksanakan tugas sesuai dengan kemampuan dan yang kita harapkan.

Sebagai pengelola pendidikan sepantasnya kepala sekolah memiliki kemauan dan kemampuan dalam bentuk kinerja sebagai kepala sekolah agar pendidikan berada dalam nuansa proses pembelajaran yang menyenangkan (enjoyfull learning) menikmati lagi dalam menjalankan tugasnya. 
UU NO. 20 Tahun 2003 pasal 3 yang berbumyi, pendidikan Nasional berfungsi mengembangkan kemampuan dan membentuk watak serta peradaban bangsa yang bermartabat dalam rangka mencerdaskan kegidupan bangsa, berujuan untuk berkembangnya potensi peserta sisik agar menjadi manusia yang beriman dan bertaqwa kepada Tuhan Yang Maha Esa, berahlak mulia, sehat, berilmu, cakap,kreatif, mandiri dan menjadi wa rga negara yang demokratis serta bertanggung jawab ( M.Quraish Syihab,2002 hal 129).

Mengupayakan guru-guru yang belum tersertifikasi untuk dapat mengikuti sertifikasi. Upaya peningkatan profesionalisme guru dapat dilakukan melalui: pertama : supervisi pendidikan, kedua : program sertifikasi, dan ketiga :tugas belajar. Bersandar dari tiga hal ini maka apa yang telah dilakukan oleh kepala sekolah sudah tepat.

Upaya kepala sekolah pada peningkatan profesionalisme guru salah satunya juga melalui supervisi kepala. Supervisi kepala adalah kepala sekolah memperhatikan dan bertanggung jawab atas perkembangan profesionalisme guru yang dibinanya.

\section{Langkah-langkah Kepala Sekolah dalam Meningkatkan Profesionalisme Guru}

Kepala sekolah merupakan seorang pejabat yang profesional dalam organisasi dan bekerja sama dengan guru-guru dalam mendidik siswa untuk mencapai tujuan pendidikan. Dengan keprofesionalan kepala sekolah ini, pengembangan profesionalisme tenaga kependidikan mudah dilakukan karena sesuai dengan fungsinya, kepala sekolah memahami kebutuhan sekolah yang ia pimpin sehingga kompetensi guru tidak hanya pada kompetensi guru tidak hanya pada kompetensi yang ia miliki sebelumnya, melainkan bertambah dan berkembang dengan baik sehingga profesionalisme guru akan terwujud. Karena tenaga kependidikan profesional tidak hanya menguasai bidang ilmu, bahan ajar, dan metode yang tepat, akan tetapi mampu memotivasi peserta didik, memiliki keterampilan yang tinggi dan wawasan yang luas terhadap dunia pendidikan.

Kepala sekolah sebagai edukator, supervisor, motivator yang harus melaksanakan pembinaan kepada para karyawan, dan para guru disekolah yang dipimpinnya karena faktor manusia merupakan faktor sentral yang menentukan seluruh gerak aktivitas suatu organisasi. Walau secanggih apapun teknologi yang digunakan tetap faktor manusia yang menentukannya.

\section{Kendala - kendala kepala sekolah dalam meningkatkan profesionalisme guru}

Serangkaian masalah yang meliputi dunia pendidikan dewasa ini masih perlu mendapat perhatian dari semua pihak. Mulai dari kualitas tenaga pendidik yang belum mencapai target hingga masalah kesejahteraan guru, pemasalahan jauh lebih kompleks dalam lingkungan pendidikan kita. Boleh dikatakan tingkat kualitas dan kompetensi guru menjadi kendala utamanya, mulai dari guru yang tidak memiliki kelayakan kompetensi untuk mengajar mata pelajaran tertentu, hingga rendahnya tingkat profesionalisme guru itu sendiri.

Masih ada beberapa guru yang kurang terpacu dan termotivasi untuk memberdayakan diri, mengembangkan profesionalitas diri atau memutahirkan pengetahuan mereka secara terus-menerus dan berkelanjutan, meskipun cukup banyak guru indnesia yang sangat rajin menaikkan pangkat mereka dan sangat 
rajin pula mengikuti program-program pendidikan kilat atau jalan pintas yang dilakukan oleh berbagai lembaga pendidikan, masih sangat banyak guru Indonesia yang kurang terpacu, terdorong, dan tergerak secara pribadi untuk mengembangkan profesi mereka sebagai guru.

Kurangnya kesempatan guru mengembangkan profesi secara berkelanjutan. Banyak guru indonesa yang terjebak pada rutinitas, pihak berwenang pun tidak mendorong guru kearah pengembangan kompetensi dari ataupun karier.

\section{Kesimpulan}

Berdasarkan temuan penelitian dan pembahasan hasil penelitian mengenai peran kepala sekolah dalam meningkatkan profesionalisme guru smk di kecamatan curahdami, dapat ditarik kesimpulan bahwa Memberdayakan kompetensi yang dimiliki oleh guru, mengadakan pelatihan, proram pembinaan secara khusus seperti sertifikasi, dalam sertifikasi tercermin adanya suatu uji kelayakan dan kepatutan yang harus dijalani seorang guru, terhadap kriteriakriteria yang secara ideal telah ditetapkan. Dengan adanya sertifikasi akan memacu semangat guru untuk memperbaiki diri, meningkatkan kualitas ilmu, dan profesionalisme dalam dunia pendidikan. meningkatkan kreatifitas guru yaitu dengan merangsang dan membangkitkan semangat guru dalam mengajar.

\section{Saran}

Berdasarkan kesimpulan dan data yang ditemukan dilapangan, maka untuk meningkatkan peran kepala sekolah dalam meningkatkan profesionalisme guru SMK di kecamatan curahdami ada beberapa saran yang perlu disampaikan kepada berbagai pihak terkait, antara lain:

1. Kepala sekolah hendaknya berusaha dan komitmen terhadap pengembangan kinerja para personal (terutama para guru)kearah profesionalisme yang diharapkan, untuk mnciptakan itu semua maka pimpinan sekolah dasar negeri harus memperhatikan kepemimpinan Demokrasi kolaborasi.

2. Kepala sekolah hendaknya mengoptimalkan peran MGMP sebagai wadah untuk meningkatkan profesionalisme guru dengan teknik maupun metode pembelajaran yang bervariatif

3. Kepala sekolah hendaknya melihat fakor lata belakang pendidikan guru, pengalaman mengajar dan keadaan kesejahtraan guu dalam meningkatkan profesionalisme.

4. Guru hendaknya lebih meningkatkan lagi kompetensi profesionalnya secara berkesinambungan dengan lebih aktif mengikuti pendidikan, pelatihan baik yang dilaksanakan oleh sekolah dasar negeri maupun dinas pendidikan

5. Para guru disarankan untuk selalu mengingatkan kepada siswa akan pentinganya memiliki kemampuan membaca cepat siswa, sebab semakin tinggi kemampuan membaca cepat siswa maka semakin banyak pola informasi dan pengetahuan yang mereka dapat. 


\section{DAFTAR PUSTAKA}

Arikunto, S. 2010. Prosedur Penelitian: Sesuatu Pendekatan Praktik. Jakarta: Bina Aksara

Rosilawati, A. 2001.Profesionalisme . Bandung: Pustaka Belajar

Tohirin, 2011. Metode Penelitian Kualitatif Dalam Pendidikan dan Bimbingan Konseling. Bumi Lancang Kuning

Arikunto, S. 1983. Prosedur Penelitian: Sesuatu Pendekatan Praktik. Jakarta: Bina Aksara

Davies, F.1983. Introduction Reading. London: pinguin Books.

Abdurrahman Mulyono. (2010). Pendidikan Bagi Anak Berkesulitan Belajar, Jakarta: Rineka Cipta.

Achdiat Maman, (2009), Pembentukan Profesional Keguruan, Bandung:PT Remaja Rosdakaya.

Hakam M Naja , (2003), Undang - undang Guru dan Dosen, Jakarta: Pustaka Pelajar.

Jasin Anwar, (2005), Profesionalisme Guru Dalam Rangka Peningkatan Mutu Sumber Daya Manusia, Jakarta: Intermassa.

Munir Abdullah, (2010), Menjadi Kepala Sekolah Efefit, Jogjakarta: Ar-Ruzz Media.

Hamalik Oemar, (2006), pendidikan Guru Berdasarkan Pendekatan Kompetensi, Jakarta: PT. Bumi Aksara

Kunandar, (2009), Guru Profesionalisme Implementasi Kurikulum Tingkat Satuan Pendidikan, Jakarta:Intermassa.

Moh. Uzer Usman, (2009), Menjadi Guru Profesional, Bandung: Remaja RosdaKarya.

Munir Abdullah, (2010), Menjadi Kepala Sekolah Efetitif, Jogjakarta: Ar-Ruzz.

Piet, A Sohertian, (2008), Profil Pendidikan Profesionalisme, Yogyakarta: Andi Offset.

Ruswandi Uus, dkk, (2010), Pengembangan Kepribadian Guru, Bandung: Cv. Insan.

Sagala Syaiful, (2013), Kemampuan Profesional Guru dan Tenaga Kependidikan, Bandung: Alfabeta.

Saudagar Faschrudin, (2013), Pengembangan Profesionalisme Guru, Jakarta: Gaung Persada.

Soetjipto, dkk, (2008), Profesi Keguruan, Jakarta: Rineka Cipta.

Wahyudi, (2012), Kepemimpinan Kepala Sekolah Dalam Organisasi Pembelajaran, Bandunf: Alfabe 